\title{
SISTEM INFORMASI PENJUALAN PADA CV. BUMEN TUNGGAL ABADI MENGGUNAKAN METODE SDLC
}

\author{
Fitrianto Adi Pratama1, Rudi Hermawan², Sutrisno ${ }^{3}$ \\ 1,2,3 Universitas Indraprasta PGRI \\ Jalan Raya Tengah No 80, Kelurahan Gedong, Pasar Rebo, Jakarta Timur \\ 1. pratamaadifit@gmail.com, ${ }^{2}$ rh001unindra@gmail.com, $\underline{{ }^{3} \text { sutrisno3831@gmail.com }}$
}

\begin{abstract}
ABSTRAK
CV. Bumen Tunggal Abadi merupakan perusahaan yang beroperasi pada bidang penjualan alat tulis kantor. Namun implementasi administrasi penjualan masih dikerjakan dengan cara tulis tangan di mana pendapatan, penyimpanan serta pembuatan laporan masih menggunakan media kertas. Hal ini mengakibatkan tidak efisiennya dalam pengelolaan data penjualan karena memakan waktu yang cukup lama dan resiko kesalahan manusia yang cukup besar. Tujuan penelitian ini yaitu membangun sistem informasi penjualan pada CV. Bumen Tunggal Abadi agar sistem pengolahan data penjualan berjalan efektif dan efisien. Metode penelitian yang digunakan adalah metode SDLC dan tahap pengujian dilakukan dengan cara BlackBox Testing. Selain itu peneliti juga menggunakan metode kepustakaan untuk mendapatkan data yang lebih lengkap. Hasil penelitian ini adalah sistem informasi pengolahan data penjualan yang sudah terkomputerisasi yang dapat meningkatkan dan mempermudah kinerja karyawan pada CV. Bumen Tunggal Abadi.
\end{abstract}

Kata Kunci: Sistem Informasi, Penjualan, BlackBox Testing

\begin{abstract}
$C V$. Bumen Tunggal Abadi is a company that operates in the sale of office stationery. However, the implementation of sales administration is still done by hand where income, storage and report generation still use paper media. This results in inefficiency in managing sales data because it takes a long time and the risk of human error is quite large. The purpose of this study is to build a sales information system on CV. Bumen Tunggal Abadi so that the sales data processing system runs effectively and efficiently. The research method used is the SDLC method and the testing phase is carried out by means of BlackBox Testing. In addition, researchers also use the library method to obtain more complete data. The results of this study is a computerized sales data processing information system that can improve and facilitate employee performance at CV. Bumen Tunggal Abadi.
\end{abstract}

Key Word: Information System, Sales, BlackBox Testing

\section{PENDAHULUAN}

Seiring kemajuan teknologi informasi yang ada saat ini, pengolahan data dapat dikerjakan dengan mudah, dapat memperoleh informasi dengan akurat, menghemat waktu dan dengan biaya yang dikeluarkan lebih efisien. Keunggulan ini yang menyebabkan teknologi informasi saat ini banyak berperan serta dalam segala bidang dan aspek kehidupan yang ada dan berkembang sesuai dengan kebutuhan masyarakat.

CV. Bumen Tunggal Abadi merupakan perusahaan yang beroperasi pada bidang penjualan alat tulis kantor. Sistem informasi penjualan pada perusahaan tersebut masih dikerjakan dengan cara tulis tangan di mana pendapatan, penyimpanan dan pembuatan laporan masih menggunakan media kertas. Hal ini menyebabkan tidak efisiennya dalam pengelolaan data penjualan karena memakan waktu yang cukup lama dan resiko kesalahan manusia yang cukup besar. Untuk itu sangat diperlukan sistem yang terkomputerisasi untuk memudahkan dalam kegiatan proses penginput an data, transaksi pembelian serta transaksi penjualan dan juga untuk mengetahui stok barang yang masuk dan keluar sehingga menjadi lebih efektif dan efisien (Fatkhudin, 2016).

Dengan ini penulis membuat Sistem informasi penjualan yang diharapkan dapat menyelesaikan permasalahan yang ada di perusahaan.

Tujuan penelitian ini, untuk memberikan solusi untuk CV. Bumen Tunggal Abadi untuk pengolahan data yang lebih baik dengan menggunakan sistem informasi penjualan 
yang terkomputerisasi sehingga pengolahan data penjualan menjadi efektif dan efisien.

Perancangan merupakan suatu kegiatan membuat desain teknis berdasarkan evaluasi yang telah dilakukan pada kegiatan analisis (Hartami Santi, 2020).

Sistem Informasi yaitu suatu sistem dalam suatu organisasi yang mempertemukan kebutuhan pengolahan transaksi harian yang mendukung fungsi operasi organisasi yang bersifat manajerial dengan kegiatan strategi dari suatu organisasi kepada pihak luar dengan informasi yang diperlukan guna pengambilan keputusan (Yunaeti Anggraeni \& Irviani, 2017) .

Sistem Informasi di dalam suatu organisasi yang mempertemukan kebutuhan pengelolaan transaksi harian dan bersifat manajerial dan menyediakan pihak luar tertentu dengan laporan-laporan yang dibutuhkan (Hutahaean, 2015).

Penjualan adalah tentang menyakinkan prospek untuk membeli atau menggunakan jasa yang ditawarkan, jadi penjualan adalah tentang memperoleh kontrak bisnis (closing business opportunities) (M. Ruky, 2019).

Keputusan pembelian konsumen merupakan keputusan terakhir yang membeli barang dan jasa untuk konsumsi pribadi (Kotler, 2014).

Sebagai bahan acuan penelitian, peneliti menggunakan referensi untuk mengangkat topik penelitian sebagai berikut : Penelitian oleh (Excelina et al., 2021) yang berjudul Perancangan Sistem Informasi Penjualan pada PT Royal Agung Berdikari dimana hasil penelitian tersebut menunjukkan aktivitas operasional yang lebih mudah sehingga mampu meminimalisir waktu yang dibutuhkan untuk mengelola data penjualan. Selanjutnya penelitian oleh (Marsudi et al., 2020) yang berjudul Perancangan Sistem Aplikasi Penjualan Sparepart pada Toko Kim Jaya Motor dimana hasil penelitian tersebut memudahkan pengolahan data penjualan sparepart dan proses pengerjaan laporan dapat dikerjakan dengan cepat dan akurat.

Manfaat penelitian ini, perusahaan dapat menggunakan sistem informasi penjualan ini agar mampu meningkatkan kinerja administrasi keuangan dalam pengolahan data penjualan pada CV. Bumen Tunggal Abadi serta dapat mempermudah administrasi keuangan dalam pengerjaan laporan yang cepat dan akurat.

\section{METODE PENELITIAN}

Dalam pengembangan sistem yang terdapat pada CV. Bumen Tunggal Abadi, penulis menggunakan SDLC (Software Development Life Cycle atau sering disebut juga System Development Life Cycle yaitu pengembangan atau mengupgrade sebuah sistem software menggunakan model dan tata cara yang digunakan seseorang untuk mengupgrade sebuah sistem software sebelumnya (A. S., Rosa dan Shalahuddin, 2018).

Tempat penelitian dalam proses pengambilan data untuk pembangunan sistem, yaitu pada CV. Bumen Tunggal Abadi yang berada di Jalan Pinang Kalijati No. 56 Pondok Labu, Cilandak, Jakarta Selatan.

Beberapa proses dalam pengumpulan data antara lain :

\section{Observasi}

Observasi yaitu metode pengumpulan data yang dipakai untuk mengamati tindakan, perilaku, proses. Observasi dilakukan untuk mengamati apa yang terjadi di lapangan, misalnya di pabrik, kantor, pasar, sekolah dan sebagainya (Sayidah, 2018).

2. Wawancara

Wawancara merupakan proses komunikasi antara peneliti dengan sumber data dalam rangka mencari data yang bersifat word view untuk mengungkapkan makna yang ada pada masalah-masalah yang diteliti (Rukajat, 2018).

3. Studi Literatur

Studi literatur menguraikan tentang segala bentuk teori dasar yang cocok dengan topik masalah penelitian. Studi literatur juga berfungsi untuk memunculkan konsep atau teori yang menjadi dasar studi yang unik dalam suatu penelitian (Laut Mertha Jaya, 2020).

Bahasa pemrograman yang digunakan adalah java. Java adalah bahasa pemrograman yang biasa dipakai untuk mengembangkan sebuah software, website, artificial intelligence yang 
bisa berkomunikasi melalui internet ataupun jaringan lainnya (Haryanto, 2011).

\section{HASIL DAN PEMBAHASAN}

Hasil penelitian pada CV. Bumen Tunggal Abadi adalah rancangan sistem informasi penjualan yang berguna untuk mempermudah perusahaan dalam menangani permasalahan data penjualan sehingga pengolahan data tersebut menjadi lebih efektif dan efisien (Fatkhudin, 2016).

Berdasarkan masalah yang terdapat pada CV. Bumen Tunggal Abadi, maka tahap pengujian dilakukan dengan cara BlackBox Testing. Cara pengujian dilakukan dengan menjalankan aplikasi Sistem Informasi dan melihat hasil output-nya apakah telah sesuai dengan hasil yang diharapkan, yaitu :

\begin{tabular}{|c|c|c|c|}
\hline No & $\begin{array}{l}\text { Skenario } \\
\text { Pengujian }\end{array}$ & $\begin{array}{l}\text { Hasil yang } \\
\text { diharapkan }\end{array}$ & Kesimpulan \\
\hline 1 & $\begin{array}{l}\text { Memasukan } \\
\text { username atau } \\
\text { password atau } \\
\text { keduanya } \\
\text { yang belum } \\
\text { tersimpan } \\
\text { pada database } \\
\text { lalu klik } \\
\text { tombol } \\
\text { "Login". }\end{array}$ & $\begin{array}{l}\text { Sistem akan } \\
\text { menolak } \\
\text { akses login } \\
\text { dan } \\
\text { menampilka } \\
\text { n pesan } \\
\text { "Username } \\
\text { atau } \\
\text { Password } \\
\text { Salah". }\end{array}$ & Berhasil \\
\hline 2 & $\begin{array}{l}\text { Memasukan } \\
\text { username dan } \\
\text { password } \\
\text { yang sesuai } \\
\text { dalam } \\
\text { database lalu } \\
\text { klik "Login". }\end{array}$ & $\begin{array}{l}\text { Sistem akan } \\
\text { menampilka } \\
\text { n pesan } \\
\text { "Login } \\
\text { Berhasil" } \\
\text { dan menuju } \\
\text { halaman } \\
\text { utama. }\end{array}$ & Berhasil \\
\hline 3 & $\begin{array}{l}\text { Memilih } \\
\text { menu Barang. }\end{array}$ & $\begin{array}{l}\text { Sistem } \\
\text { menampilka } \\
\text { n Halaman } \\
\text { Barang yang } \\
\text { berisikan } \\
\text { form dan } \\
\text { tabel data } \\
\text { yang } \\
\text { terkoneksi } \\
\text { dengan } \\
\text { database. }\end{array}$ & Berhasil \\
\hline 4 & $\begin{array}{l}\text { Pada halaman } \\
\text { Barang, lalu } \\
\text { isi form dan } \\
\text { klik "simpan" }\end{array}$ & $\begin{array}{l}\text { Data Barang } \\
\text { akan } \\
\text { bertambah } \\
\text { ke dalam } \\
\text { database. }\end{array}$ & Berhasil \\
\hline 5 & $\begin{array}{l}\text { Pada halaman } \\
\text { Barang pilih } \\
\text { baris data } \\
\text { pada tabel dan }\end{array}$ & $\begin{array}{l}\text { Data yang } \\
\text { terpilih dari } \\
\text { tabel akan } \\
\text { termuat }\end{array}$ & Berhasil \\
\hline
\end{tabular}

\begin{tabular}{|lll|}
\hline $\begin{array}{ll}\text { klik tombol } \\
\text { "edit", ubah } \\
\text { data lalu klik } \\
\text { "simpan". }\end{array}$ & $\begin{array}{l}\text { pada form } \\
\text { dan data } \\
\text { tersebut } \\
\text { akan ter- } \\
\text { update pada } \\
\text { database } \\
\text { dan tabel } \\
\text { data }\end{array}$ \\
\hline 6 & Pada halaman & Data yang Bang \\
Barang pilih & terpilih dari \\
baris data & tabel akan \\
pada tabel dan & termuat \\
klik tombol & pada form \\
"hapus", & dan data \\
& tersebut \\
& akan \\
& terhapus \\
& pada \\
& database \\
& dan tabel \\
& data \\
\hline
\end{tabular}

\section{Use Case Diagram}

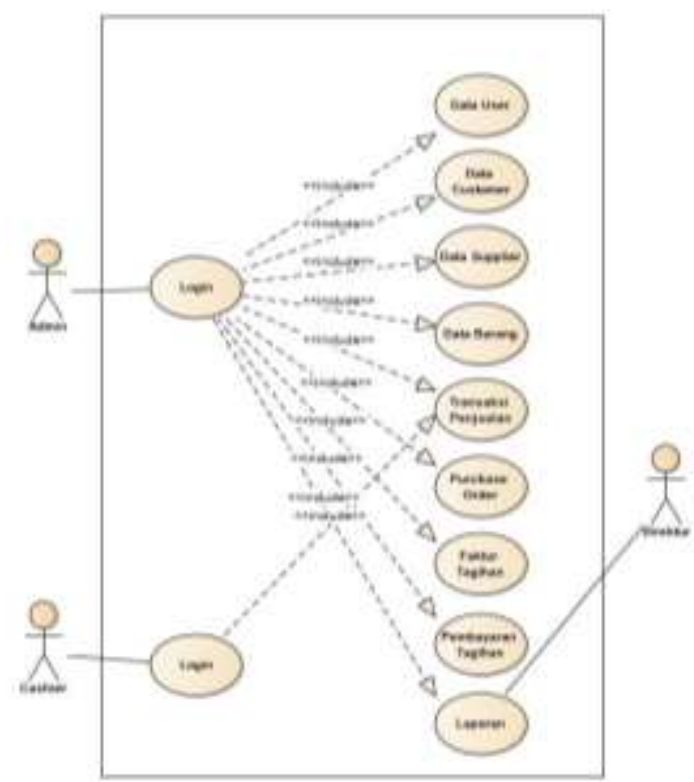

Gambar 1. Use Case Diagram

Use case menggambarkan external view dari sistem yang akan kita buat modelnya. Gambar tersebut menjelaskan use case diagram sistem informasi yang diusulkan pada pada $\mathrm{CV}$. Bumen Tunggal Abadi.

\section{Activity Diagram}

activity diagram login merupakan aktivitas pertama yang akan dilewati user ketika mengakses aplikasi dengan memasukkan email dan password. 


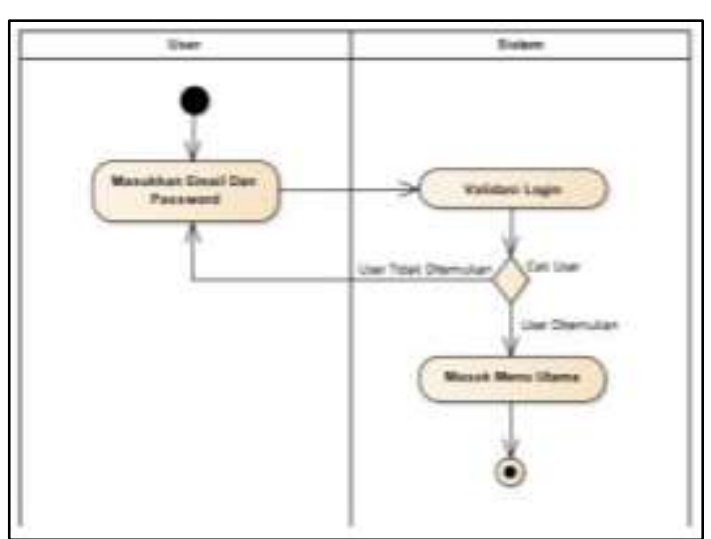

Gambar 2. Activity Diagram Login

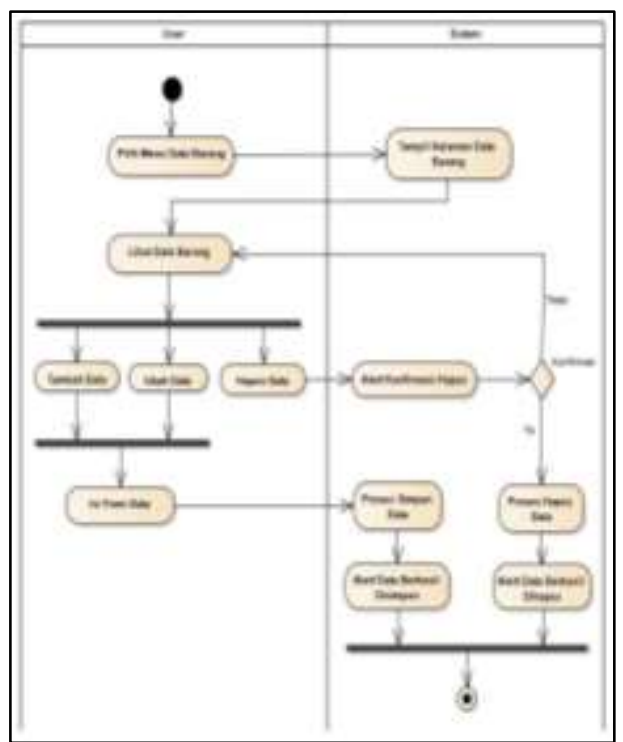

Gambar 3. Activity Diagram Data Barang

Gambar activity diagram data barang menjelaskan dalam mengelola data barang yang ada pada aplikasi.

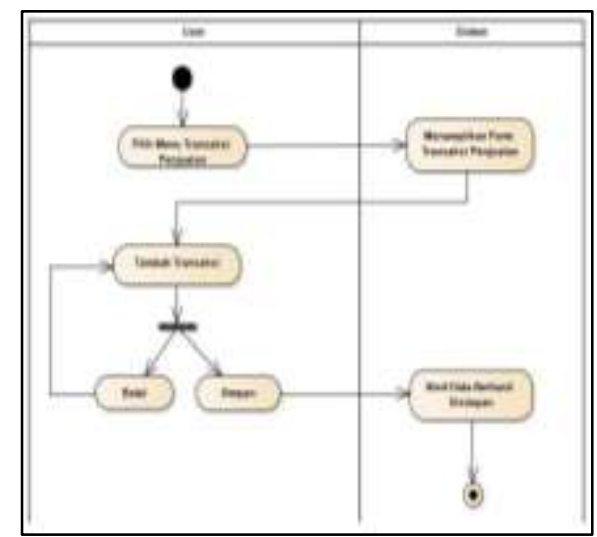

Gambar 4. Activity Diagram Transaksi Penjualan

Gambar activity diagram transaksi penjualan menjelaskan bagaimana mengelola transaksi penjualan yang ada pada aplikasi.

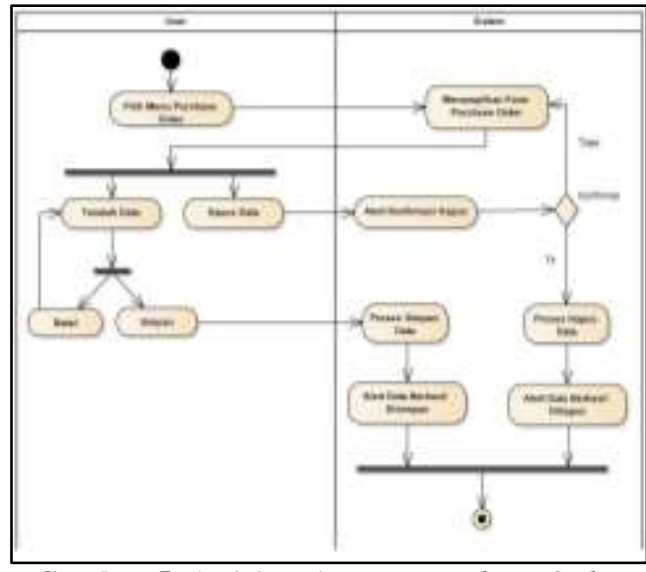

Gambar 5. Activity Diagram Purchase Order

Gambar activity diagram purchase order menjelaskan bagaimana mengelola purchase order yang ada pada aplikasi.

\section{Sequence Diagram}

Sequence diagram menggambarkan sejumlah objek dan pesan yang diletakkan di antara objek-objek di dalam usecase.

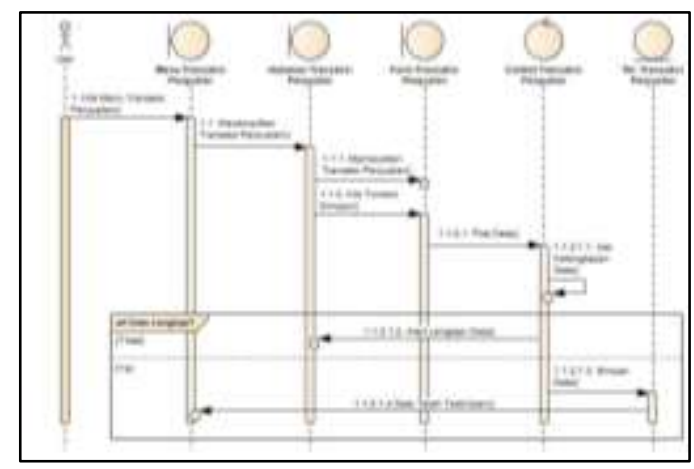

Gambar 6. Sequence Diagram

\section{Tampilan Rancang Layar}

Tampilan Layar Login

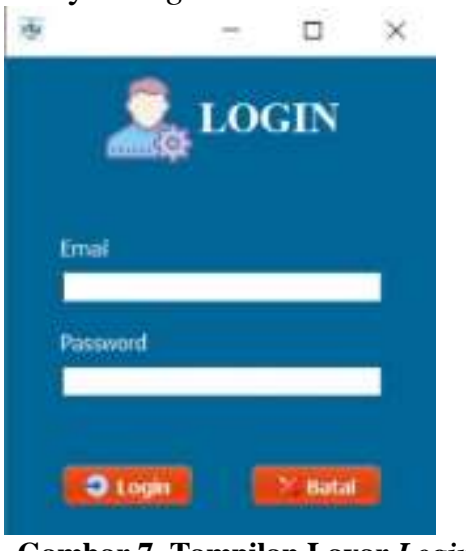

Gambar 7. Tampilan Layar Login

Halaman login ini akan tampil saat membuka aplikasi penjualan CV. Bumen Tunggal 
Abadi. Jika email dan password yang dimasukkan benar, sistem akan memeriksa hak akses user sehingga sistem dapat menampilkan halaman utama sesuai dengan hak akses user.

Tampilan Menu Utama

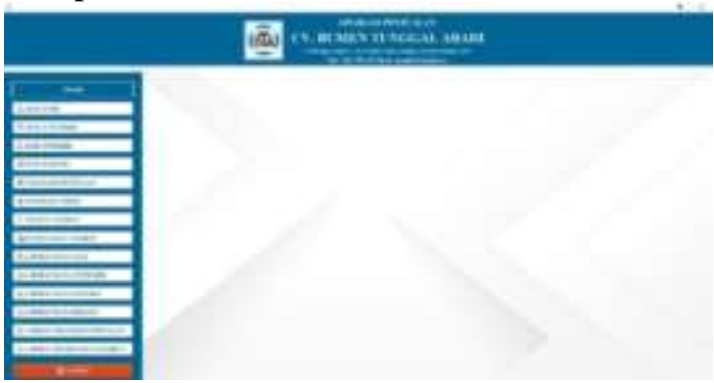

Gambar 8. Tampilan Layar Menu Utama

Menu utama ini akan tampil ketika user berhasil melakukan login sesuai dengan hak akses user. Pada menu utama ini terdapat menu data user, menu data customer, menu data supplier, menu data barang, menu transaksi penjualan, menu purchase order, menu faktur tagihan, menu pembayaran tagihan dan laporan-laporan.

Tampilan Layar Data Barang

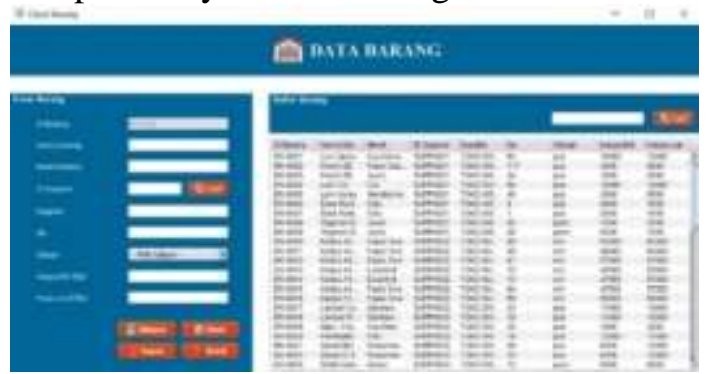

Gambar 9. Tampilan Layar Data Barang

Data barang akan tampil setelah admin masuk ke aplikasi dan memilih menu data barang. Pada menu ini terdapat beberapa fitur yaitu admin dapat menambah, merubah dan menghapus data barang.

Tampilan Layar Transaksi Penjualan

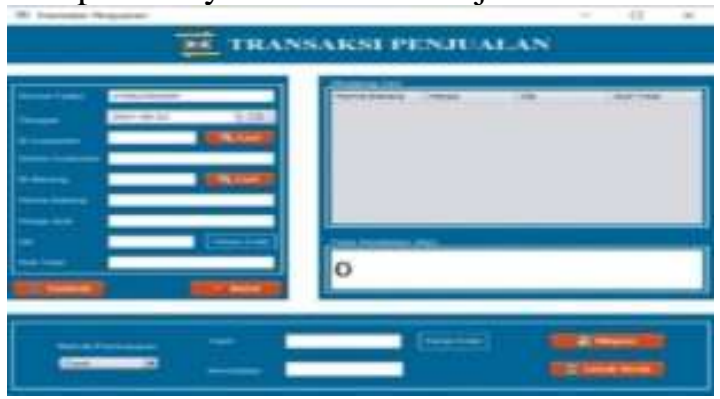

Gambar 10. Tampilan Layar Transaksi Penjualan
Pada tampilan ini, user menginput transaksi penjualan yang ada pada perusahaan.

Tampilan Layar Menu Purchase Order

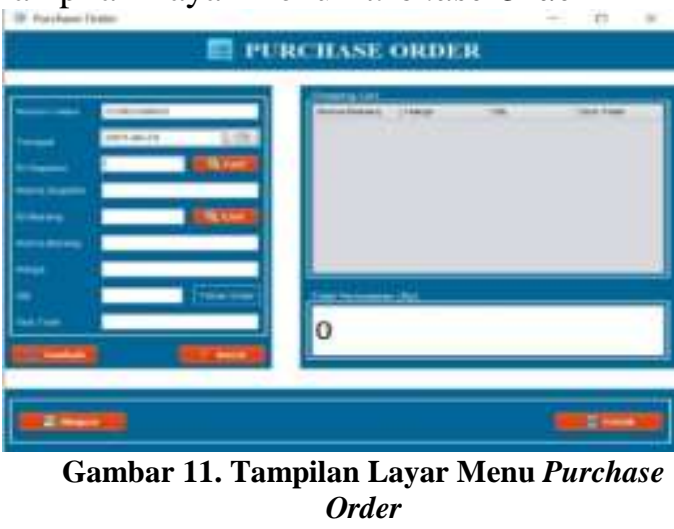

Pada tampilan ini, admin menginput purchase order pada barang yang stoknya telah menipis atau habis.

Tampilan Layar Laporan Data Barang

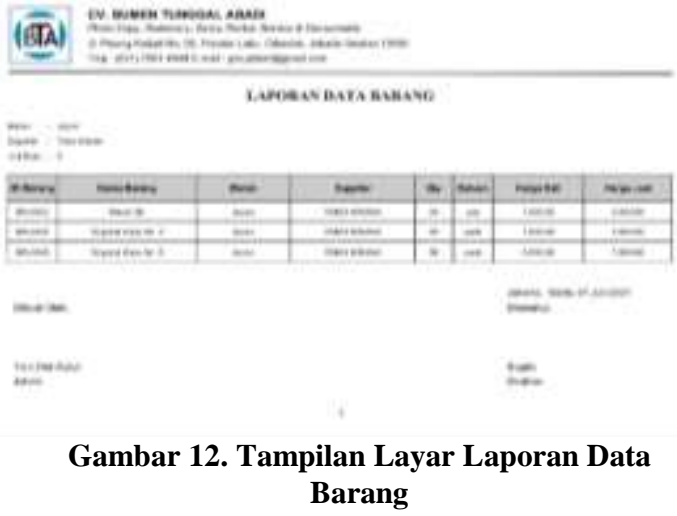

Laporan ini menampilkan seluruh data barang yang ada pada perusahaan.

Tampilan Layar Laporan Transaksi Penjualan

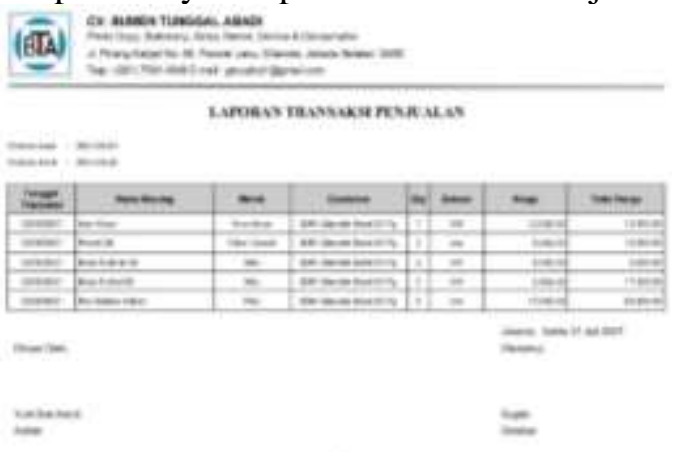

Gambar 13. Tampilan Layar Laporan Transaksi Penjualan

Laporan ini menampilkan transaksi penjualan yang ada pada perusahaan. 
Tampilan Layar Laporan Purchase Order
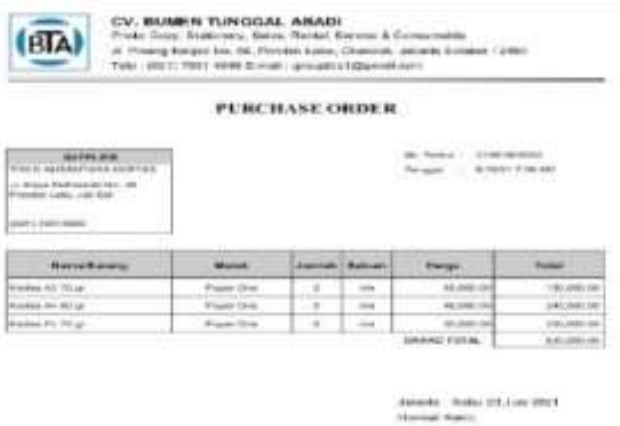

Gambar 14. Tampilan Layar Laporan Purchase Order

Laporan ini menampilkan purchase order yang ada pada perusahaan.

\section{SIMPULAN DAN SARAN}

Berdasarkan penelitian yang telah dilakukan penulis mengenai perancangan sistem informasi penjualan pada CV. Bumen Tunggal Abadi, dapat diambil kesimpulan sebagai berikut:

Sistem informasi penjualan pada CV. Bumen Tunggal Abadi ini dapat mengelola data penjualan komputer secara cepat, akurat dan tepat serta memudahkan karyawan dalam bekerja.

Dengan adanya sistem ini dapat meningkatkan efisien dan efektifitas kinerja pada CV. Bumen Tunggal Abadi.

Dengan menggunakan sistem yang sudah terkomputerisasi diharapkan dapat meminimalis adanya kehilangan data dalam proses penjualan pada CV. Bumen Tunggal Abadi.

Berdasarkan hasil evaluasi terhadap sistem informasi yang penulis bangun terdapat beberapa saran untuk pengembangan diantaranya adalah sitem informasi penjualan ini masih dapat dikembangkan seiring dengan berkembangnya spesifikasi kebutuhan pengguna, terutama dalam hal tampilan ada baiknya dibuat tampilan yang lebih menarik dan dikembangkan lebih lanjut. Masih banyak menu lain yang dapat dikembangkan dalam perangkat lunak ini misalnya return transaksi pembelian dan transaksi penjualan, pengembangan tersebut tentunya dapat meningkatkan mutu sistem yang lebih baik.

\section{DAFTAR PUSTAKA}

A. S., Rosa dan Shalahuddin, M. (2018). Rekayasa Perangkat Lunak Terstruktur dan Berorientasi Objek. Informatika.

Excelina, D., Astuti, P., \& Mufti, A. (2021). Perancangan Sistem Informasi Penjualan pada PT Royal Agung Berdikari. Jurnal Riset Dan Aplikasi Mahasiswa Informatika (JRAMI), 2(02), 310-317. https://doi.org/10.30998/jrami.v2i02.12 66

Fatkhudin. (2016). Toko Elektronik Lubada Jaya Kajen Dengan. Jurnal Digit, 6(1), 23-36.

Hartami Santi, I. (2020). Analisa Perancangan Sistem. PT. Nasya Expanding Management.

Haryanto, B. (2011). Esensi-esensi Bahasa Pemrograman Java. Andi.

Hutahaean, J. (2015). Konsep Sistem Informasi. Deepublish.

Kotler, P. \& K. L. K. (2014). Principle Of Marketing (15th ed.). Pearson Pretice Hall, Inc.

Laut Mertha Jaya, I. M. (2020). Metode Penelitian Kuantitatif dan Kualitatif. Anak Hebat Indonesia.

M. Ruky, S. (2019). Mengelola Perusahaan Jasa Profesional. PT. Gramedia Pustaka Utama.

Marsudi, D., Mufti, A., \& Lestari, M. (2020). Perancangan Sistem Aplikasi Penjualan Sparepart pada Toko Kim Jaya Motor. Jurnal Riset Dan Aplikasi Mahasiswa Informatika (JRAMI), 1(03), 376-383. https://doi.org/10.30998/jrami.v1i03.38 2

Rukajat, A. (2018). Pendekatan Penelitian Kualitatif (Qualitative Research Approach). Deepublish.

Sayidah, N. (2018). Metodologi Penelitian. In Metodologi Penelitian Disertai Dengan Contoh Penerapannya Dalam Penelitian. Zifatama Jawara.

Yunaeti Anggraeni, E., \& Irviani, R. (2017). Pengantar Sistem Informasi. Andi. 